\title{
Functionalization Of Corruption Laws In Criminal Judgment Rules
}

\author{
Amir Akbar Nurul Qomar*) and Amin Purnawan**)
}

*) Student of Masters (S2) of Law Faculty of Law Unissula and Head of Section for Special Crimes, Banjarnegara District Attorney, Indonesia, email: amir.akbarqomar@gmail.com

${ }^{* *}$ ) Faculty of Law Universitas Islam Sultan Agung

\begin{abstract}
The purpose of this research is to review and analyze the functionalization of the Corruption Law in the decisions of criminal justice judges. The research method used is Sociological juridical method with descriptive research specifications. The data used for this research are primary and secondary data taken by field observation, interview, and literature study methods. The conclusion from the results of the research is that the decision of the Semarang District Court Number 25 / Pid.Sus-TPK / 2019 / PN Smg provides an overview of the judicial process which is at the court stage as a form of functionalization of the Corruption Law which spells out the flow of the trial in cases of criminal corruption collectively by a Head of District in Wonogiri Regency. In the decision taking into account the provisions of Article 12 letter e of Act No. 31 of 1999 in conjunction with Act No. 20 of 2001 concerning Eradication of Corruption.
\end{abstract}

Keywords: Functionalization, Anti Corruption Act, Decision of Criminal Court Judges

\section{Introduction}

In this case, corruption is an act that raises a legal sanction in the form of criminal law. Until now, corruption in Indonesia is still one of the causes for the deterioration of state finances. ${ }^{1}$ This is because corruption in Indonesia occurs in a systemic, massive and structured manner so that it is not only detrimental to the state's financial condition, but also violates the social and economic rights of the community at large. ${ }^{2}$ The results of the 2006 Political and Economic Risk Consultancy Ltd (PERC) study, for example, placed this country in the third most corrupt country among other Asian countries, after China and Vietnam. That same year, Transparency International, a global anti-corruption coalition, released an annual index of perceptions of the business community and academia on corruption in more than 50 countries. From this index, Indonesia is included in the top 10 countries with the highest degree of corruption, a worse condition was shown by the Transparency International (TI) in 2007. Indonesia is placed as the third most corrupt country in the world, and that position has not changed when in

\footnotetext{
${ }^{1}$ Abdul Haris, Umar Ma'ruf, dan Sri Kusriyah, Role And Function Of Attorney In Order To Optimize The Prevention Of Corruption Through Establishment Of TP4P/D (Case Studies In State Attorney Of Grobogan), Jurnal Daulat Hukum, Vol.2 No.4, November 2019, url: http://jurnal.unissula.ac.id/index.php/RH/issue/view/398

${ }^{2}$ Imanudin, Handling Policy on Corruption Crime in Polres Tasikmalaya, Jurnal Daulat Hukum, Vo.1 No.2, June 2018, url: http://jurnal.unissula.ac.id/index.php/RH/issue/archive
} 
2007. The next time this institution announced a corruption perceptions index (CPI) against 99 countries. New in 2009,3

Lord Acton (John Emerich Edward Dalberg Acton) in his letter to Bishop Mandell Creighton wrote a phrase that connects "Corruption" to "Power", namely "Power tends to corrupt, and absolute Power corrupts absolutely", that power tends to corruption and power absolute tendencies to absolute corruption. ${ }^{4}$ This expression is a condition that is currently happening in Indonesia.

The Corruption Eradication Law specifically regulates its own procedural law for law enforcement for perpetrators of corruption, in general it is distinguished from other specific criminal handling. This is because corruption is an extra ordinary crime that must take precedence over other criminal acts. ${ }^{5} \mathrm{As}$ regulated in Act No. 31 of 1999 as amended by Act No. 20 of 2001 concerning amendments to Act No. 31 of 1999 concerning Eradication of Corruption (hereinafter referred to as the PTPK Law). ${ }^{6}$

Act No. 31 of 1999 as amended by Act No. 20 of 2001 is intended to tackle and eradicate corruption. Criminal politics is a corruption eradication strategy inherent in this law. Why the political dimension of crime does not work is related to the law enforcement system in the country which is not egalitarian. The prevailing law enforcement system can place high-level corruptors above the law. The law enforcement system which is not conducive to a democratic climate is exacerbated by the existence of a amnesty institution for corrupt conglomerates based only on taste, not by legal considerations. ${ }^{7}$

Eradicating corruption must always be a priority in the government's agenda to be tackled seriously and urgently and as part of a program to restore the trust of the people and the international community in order to increase the economic growth of a country concerned, including Indonesia. ${ }^{8}$ Criminal law enforcement, like any law enforcement process in general, involves at least three related factors, namely statutory factors, law enforcement agencies / agencies and legal awareness factors. The discussion of these three factors can be related to the division of the three components of the legal system, namely legal substance, legal structure and legal culture. In this case, the role of the Corruption Eradication Act is the basis for law enforcers in carrying out the criminal justice process for corruption as a statutory factor in the law enforcement process.

\section{Research Methods}

\footnotetext{
${ }^{3}$ Hamid Basyaib, 2004, Penyebaran Korupsi Luar Biasa, Jurnal Resonansi, Special Edition, p. 67-72

4 Ermansjah Djaja, Meredesain Pengadilan Tindak Pidana Korupsi Implikasi Putusan Mahkamah Konstitusi Nomor 012-016-019/PPU-IV/2006, Jakarta Timur, Sinar Grafika, p. 1

5IGM Nurdjana, 2009, Sistem Hukum Pidana dan Bahaya Laten Korupsi (Problematik Sistem Hukum Pidana dan Implikasinya pada Penegakan Hukum Tindak Pidana Korupsi), Total Media, Yogyakarta, p. 156.

${ }^{6}$ Junever Girsang, 2012, Penyalahgunaan Kekuasaan Aparat Penegak Hukum dalam Penanganan Tindak Pidana Korupsi, Jakarta, JG Publising, p. 7-8

${ }^{7}$ Evi Hartanti, 2005, Tindak Pidana Korupsi, Sinar Grafika, Jakarta, p. 4

${ }^{8}$ Cipto Dwi Leksana, dan Rakhmat Bowo Suharto, Implementation of Cooperation Agreement Between the Ministry of Internal Affairs, Police, Attorney General Office (Ago) in Handling and Crime Of Corruption in Indonesia, Jurnal Daulat Hukum, Vol.2 No.1, March 2019, url: http://jurnal.unissula.ac.id/index.php/RH/article/view/4217/2923
} 
To conduct a study in this study the author uses the sociological juridical method (social legal research) to study and discuss the problems raised. This research uses this type of research with descriptive methods. Data collection methods used include field research, interviews, and literature study or document study. The data that has been obtained are then analyzed by qualitative analysis.

\section{Results And Discussion}

Several considerations of lawmakers include elements of being against the law in both formal and material terms in Act No. 31 of 1999 in conjunction with Act No. 20 of 2001 concerning Eradication of Corruption Crimes. First, considering that corruption occurs systematically and extensively, not only detrimental to the country's finances and economy, but also a violation of the social and economic rights of society at large, so that it is classified as an extra ordinary crime, its eradication must be carried out in an extraordinary manner; second, the impact of criminal acts of corruption so far, apart from harming the country's finances and economy, also hinders the growth and continuity of national development which demands high efficiency; and third, in an effort to respond to the development of legal needs in society, ${ }^{9}$

Investigation, prosecution and examination in court proceedings in cases of criminal acts of corruption must take precedence over other cases in order to resolve them as quickly as possible which is also a manifestation of the implementation of the principle of rapid trial that exists in the Indonesian criminal justice system as contained in Article 4 paragraph (2) Act No. 482009 concerning Judicial Power which reads: "The trial is carried out simply, quickly and at low cost".

According to Andi Astara's statement as a judge who is also the author's source in research at the Semarang District Court, for the sake of investigation in the criminal justice stage, the suspect of corruption is obliged to provide information about all his assets and the assets of his wife or husband, children, and every property. persons or corporations known and / or suspected of having a relationship with the criminal act of corruption by the suspect. Investigators, public prosecutors or judges are authorized to request information from banks regarding the financial condition of a suspect or defendant, and requests for information from the bank are submitted to the Governor of Bank Indonesia in accordance with the prevailing laws and regulations. Investigator, public prosecutor, or the judge may ask the bank to block a deposit account belonging to a suspect or defendant that is suspected of being the result of corruption. In the event that the results of the examination of a suspect or defendant do not obtain sufficient evidence, at the request of the investigator, public prosecutor or judge, the bank will also lift the blocking on that day. Investigators in the investigation stage have the right to open, examine and confiscate letters and shipments by post, telecommunications or other means that are suspected of having links to a criminal case of corruption under investigation. ${ }^{10}$

\footnotetext{
${ }^{9}$ Asrianto Zainal, Penegakan Hukum Tindak Pidana Korupsi Oleh Kejaksaan, Jurnal Hukum, IAIN Kendari, 2017, p. 2

${ }^{10}$ Interview with Andi Astara, SH, MH, Judge at the Semarang District Court, on June 3, 2020
} 
If the suspect dies at the time of the investigation, while there has actually been a loss of state finances, the investigator will immediately submit the case files resulting from the investigation to the state attorney or submitted to the injured agency to file a civil suit against his heirs. If, at the time of examination at court, the defendant dies, while in fact there has been a loss of state finances, the public prosecutor will immediately submit a copy of the trial report file to the state attorney or submitted to the injured agency to file a civil suit against his heirs. . ${ }^{11}$

Indonesia has a reference for legal products in law enforcement to eradicate corruption, namely Act No. 31 of 1999 in conjunction with Act No. 20 of 2001 concerning Corruption Eradication. In this case, the function of the Anti-Corruption Act is to provide a reference for judges in determining the criminal elements present in the defendant in their decisions in court proceedings. ${ }^{12}$

In the case study the author on the decision of the Semarang District Court Number 25 / Pid.Sus-TPK / 2019 / PN Smg provides an overview of the judicial process which is at the court stage as a form of functionalization of the Corruption Law which is described by the flow of the trial as follows:

Taking into account the provisions of Article 12 letter e of Act No. 31 of 1999 in conjunction with Act No. 20 of 2001 concerning the Eradication of Corruption Crimes, the articles contained in Act No. 8 of 1981 concerning The Criminal Procedure Code and articles of the Act No. 46 of 2009 concerning the Corruption Crime Court and other articles of the relevant laws and regulations: ${ }^{13}$

JUDGE

1. Stating that the Defendant Drs. JOKO PRIHARTANTO, M.Si. Bin ROEKANI HADI SUTANTO has been legally and convincingly proven guilty of committing "Collective Corruption Acts";

2. Sentencing the defendant Drs. JOKO PRIHARTANTO, M.Si. Bin ROEKANI HADI SUTANTO, therefore with imprisonment of 5 (five) years, and a fine of IDR 200,000,000.00 (two hundred million rupiah), provided that if the Penalty Fines are not paid, then they are replaced by Imprisonment. for 2 (two) months;

3. To stipulate that the entire length of time the Defendant is in arrest and / or detention is deducted from the imprisonment imposed;

4. To stipulate that the Defendant remains in detention;

5. Ordered Evidence of the Letter in the form of a Special Audit Result Report on the Calculation of Detailed Use of the 2016 PRONA Activity Levies in Tirtomoyo District Number 356 / KH / KESRA / 02/2018 dated 24 September 2018 from the Inspectorate of Wonogiri Regency, as well as evidence in the form of:

a) Money as follows: (Decision Number 25 / Pid.Sus-TPK / 2019 / PN Smg)

\footnotetext{
${ }^{11}$ Jawade Hafidz, Sistem Pertanggungjawaban Perkara Korupsi Dalam Rangka Percepatan Penyelamatan Uang Negara, FH Unissula, Semarang, Jurnal Dinamika Hukum, Vol.11, February 2011, p. 128

${ }^{12}$ Miftah Anshori, Investigations of Corruption in Police Resort of Pati, Jurnal Daulat Hukum, Vol.1 No.2, June 2018, url: http://jurnal.unissula.ac.id/index.php/RH/issue/archive

${ }^{13}$ Decision Number 25 / Pid.Sus-TPK / 2019 / PN Smg
} 
b) The documents are as follows: (Decision Number 25 / Pid.Sus-TPK / 2019 / PN Smg)

6. Charge the Defendant to pay court fees amounting to IDR 5,000.00 (five thousand rupiah).

If viewed from the article that the judge handed down on the defendant, the judge can impose a sentence of a minimum sentence of 4 (four) years and a maximum of 20 (twenty) years and a fine of at least IDR 1,000,000,000.00 (one million rupiah). The criminal act of corruption as referred to in Article 12 is a formal offense as is the case with the criminal act of corruption as referred to in Article 11. In the Article which is decided in the above excerpt of the decision in the form of Article 12 letter e, it is determined that the perpetrator of the criminal act of corruption in question must hold a "position. or position ", because only an individual can hold a" position or position ", the criminal act of corruption contained in Article 12 letter e can only be committed by an individual. while the corporation cannot commit the criminal act of corruption, in this case as a civil servant or state administrator. In Article 12 letter e the elements of the criminal act of corruption are:

a. Benefiting yourself or others against the law;

b. Abusing his power;

c. Forcing someone to give something, pay, or receive a discounted payment, or to do something for himself.

In the case of Corruption at the Semarang District Court case number 25 / Pid.Sus-TPK / 2019 / PN Smg, it can be concluded that Act No. 31 of 1999 in conjunction with Act No. 20 of 2001 concerning the Eradication of Corruption Crimes is a reference for judges in The decision took into account the elements in the article that were charged with the defendant Joko Prihartanto.

The analysis in this case is that the defendant, Joko Prihartanto, is a subdistrict head in Wonogiri Regency who has included evidence in the form of documents related to the National Agrarian Operations Project (Prona) program in the sub-district where the defendant is the district head. In this case the defendant was sentenced to imprisonment for 5 (five) years, as well as a fine of IDR 200,000,000.00 (two hundred million rupiah), proven legally and convincingly guilty of committing "Collective Corruption Crime". The judge determines Article 12 letter e on the grounds that the defendant in accordance with this article is a civil servant or state administrator with juridical and non-juridical considerations as follows:

a. Basic Judicial Considerations

The basis for juridical considerations is the judge's consideration from a legal point of view. So that in deciding the criminal act of corruption Article 12 letter e Law No. 20 of 2001 in conjunction with Act No. 31 of 1999 the judge must examine carefully and carefully based on what is revealed in court, namely based on existing evidence, whether the defendant's actions meets the elements of Article 12 letter $\mathrm{e}^{14}$ that is:

1) Benefiting yourself or others against the law;

${ }^{14}$ Interview with Andi Astara, SH, MH, Judge at the Semarang District Court, on June 3, 2020 
2) Abusing his power;

3) Forcing someone to give something, pay, or receive a discounted payment, or to do something for himself.

b. Non-juridical basis for consideration

The basis for non-juridical considerations is a consideration seen from a non-legal aspect. The application of the severity of the sentence imposed on a judge is adjusted to what is the motivation and consequence of the offender's actions, especially in the application of the type of imprisonment, however in the case of certain laws it has normatively regulated certain articles concerning punishment with minimal threats such as regulated in Act No. 20 of 2001 concerning Eradication of Corruption Crime. In the case of criminal acts of corruption, besides referring to Act No. 20 of 2001 concerning the Eradication of Corruption as a functionalization of the legal products used, 15

The functionalization of the Corruption Law, which the author also includes a case study in the verdict of corruption cases in the Semarang District Court, illustrates that corruption has various types of offenses regulated on each of the criteria in the articles in the Act No. 31 of 1999 in conjunction with Act No. 20 of 2001 concerning the Eradication of Corruption as a form of legal political policy in overcoming problems faced by the State in the form of extraordinary crimes, namely corruption. Corruption laws if associated with the theory of justice, ${ }^{16}$ Hans Kelsen's view is a view that is positivist in nature, the values of individual justice can be identified by legal rules that accommodate general values, but still fulfill the sense of justice and happiness for each individual.

Functionalization Act No. 31 of 1999 in conjunction with Act No. 20 of 2001 concerning the Eradication of Corruption in providing decisions on corruption cases at the court stage in the Indonesian criminal justice system gives positivity as a form of law is a social order by regulating human actions ${ }^{17}$ In this case, those who commit criminal acts of corruption that harm the people in a satisfying way are to punish the perpetrators of corruption with their speech policies in order to give satisfaction and happiness to the public for the functioning of criminal law enforcement against corrupt behavior by state officials. ${ }^{18}$

\section{4.. Closing}

In the case study the author on the decision of the Semarang District Court Number 25 / Pid.Sus-TPK / 2019 / PN Smg provides an overview of the judicial process which is at the court stage as a form of functionalization of the Corruption Law which spells out the flow of proceedings in cases of criminal corruption collectively. The same was done by a Head of District in Wonogiri Regency. In the decision taking into account the provisions of Article 12 letter e of Act No. 31 of

15 Interview with Andi Astara, SH, MH, Judge at the Semarang District Court, on June 3, 2020
${ }^{16}$ Hans Kelsen, 2011, General Theory of Law and State, diterjemahkan oleh Rasisul Muttaqien,
Bandung, Nusa Media, p. 7
${ }^{17}$ Ragil Tri Wibowo dan Akhmad Khisni, Restorative Justice in Application for Crime Investigation on
Property, Jurnal Daulat Hukum, Vol.1 No.2, June 2018, url: http://jurnal.unissula.ac.id/index.php/RH/issue/view/284

18 Sajipto Raharjo, 1983, Hukum Dan Perubahan Sosial, Bandung, Alumni, p.127 
1999 in conjunction with Act No. 20 of 2001 concerning the Eradication of Corruption Crimes, the articles contained in Act No. 8 of 1981 concerning The Criminal Procedure Code and articles of the Act No. 46 of 2009 concerning Corruption Crime Court and other articles of the relevant laws and regulations, is sentenced to imprisonment for 5 (five) years, as well as a fine amounting to Rp.200,000,000.00 (two hundred million rupiah), provided that if the fine is not paid, then it is replaced by imprisonment for 2 (two) months.

Judges, with their freedom, play an important role in imposing criminal decisions, especially in cases of corruption. Judges should always try to improve themselves, add experience and sharpen analysis in order to determine factors that are considered rational to be used as a basis for consideration of their decisions, in order to reach decisions that have a sense of justice.

In order to achieve the objectives and Act No. 20 of 2001 in conjunction with Act No. 31 of 1999, efforts to eradicate corruption need to be corrected, actions are taken in the form of increasing the function of supervision, training of apparatus, administering administrative control, fostering discipline and increasing transparent honesty, and the government can make it expensive to lose a position due to corruption; The character of the action is also attached to the reading of the judge's decision in a trial which is declared open to the public, the meaning is that in addition to containing elements of punishment, regarding the offending of the convict's good name and honor, the announcement is also functioned as a warning to the general public not to commit a criminal act.

\section{References}

\section{Book}

Ermansjah Djaja, Meredesain Pengadilan Tindak Pidana Korupsi Implikasi Putusan Mahkamah Konstitusi Nomor 012-016-019/PPU-IV/2006, Jakarta Timur, Sinar Grafika

Evi Hartanti, 2005, Tindak Pidana Korupsi, Sinar Grafika, Jakarta

Hamid Basyaib, 2004, Penyebaran Korupsi Luar Biasa, Jurnal Resonansi, Special Edition

Hans Kelsen, 2011, General Theory of Law and State, diterjemahkan oleh Rasisul Muttaqien, Bandung, Nusa Media

IGM Nurdjana, 2009, Sistem Hukum Pidana dan Bahaya Laten Korupsi (Problematik Sistem Hukum Pidana dan Implikasinya pada Penegakan Hukum Tindak Pidana Korupsi), Total Media, Yogyakarta

Juniver Girsang, 2012, Penyalahgunaan Kekuasaan Aparat Penegak Hukum dalam Penanganan Tindak Pidana Korupsi, Jakarta, JG Publising

Sajipto Raharjo, 1983, Hukum Dan Perubahan Sosial, Bandung, Alumni

\section{Journals and Documents}

Abdul Haris, Umar Ma'ruf, dan Sri Kusriyah, Role And Function Of Attorney In Order To Optimize The Prevention Of Corruption Through Establishment Of TP4P/D 
(Case Studies In State Attorney Of Grobogan), Jurnal Daulat Hukum, Vol.2 No.4, November 2019, url: http://jurnal.unissula.ac.id/index.php/RH/issue/view/398

Asrianto Zainal, Penegakan Hukum Tindak Pidana Korupsi Oleh Kejaksaan, Jurnal Hukum, IAIN Kendari, 2017

Cipto Dwi Leksana, dan Rakhmat Bowo Suharto, Implementation of Cooperation Agreement Between the Ministry of Internal Affairs, Police, Attorney General Office (Ago) in Handling and Crime Of Corruption in Indonesia, Jurnal Daulat Hukum, Vol.2 No.1, March 2019, url: http://jurnal.unissula.ac.id/index.php/RH/article/view/4217/2923

Imanudin, Handling Policy on Corruption Crime in Polres Tasikmalaya, Jurnal Daulat Hukum, Vo.1 No.2, June 2018, url: http://jurnal.unissula.ac.id/index.php/RH/issue/archive

Jawade Hafidz, Sistem Pertanggungjawaban Perkara Korupsi Dalam Rangka Percepatan Penyelamatan Uang Negara, FH Unissula, Semarang, Jurnal Dinamika Hukum, Vol.11, February 2011

Miftah Anshori, Investigations of Corruption in Police Resort of Pati, Jurnal Internasional Daulat Hukum, Vol.1 No.2, June 2018, url: http://jurnal.unissula.ac.id/index.php/RH/issue/archive

Ragil Tri Wibowo dan Akhmad Khisni, Restorative Justice in Application for Crime Investigation on Property, Jurnal Daulat Hukum, Vol.1 No.2, June 2018, url: http://jurnal.unissula.ac.id/index.php/RH/issue/view/284

Decision Number 25 / Pid.Sus-TPK / 2019 / PN Smg 